\title{
METODE PENELITIAN KEBIJAKAN PENDIDIKAN (ALTERNATIF METODOLOGI DALAM PENYUSUNAN SKRIPSI) BAGIAN 1
}

\author{
Muhammad Iqbal ${ }^{1}$, Ahmad Muslim ${ }^{2}$ \\ Program Studi Administrasi Pendidikan, FIPPUNDIKMA \\ E-mail: empu.inst@gmail.com
}

\begin{abstract}
Abstrak: Selama ini, penelitian skripsi mahasiswa masih terbatas pada aspek yang berhubungan langsung pembelajaran atau mungkin mengenai pengelolaan kependidikan. Tidak banyak ditemukan skripsi mahasiswa kependidikan yang fokus membahas isu kebijakan. Tulisan ini merupakan tulisan pertama yang mencoba menawarkan alternatif berbeda bagi mahasiswa dalam menyelesaikan tugas skripsinya. Metode penelitian kebijakan pada dasarnya adalah sama dengan metode penelitian pada umumnya. Yang membedakannya adalah penelitian kebijakan berarti mengangkat tema mengenai kebijakan. Alternatif metode pertama yang dapat digunakan oleh mahasiswa adalah metode deskriptif, yang terdiri dari 3 jenis, yaitu deskriptif kuantitatif, deskriptif kualitatif, dan deskriptif campuran. Pemilihan jenis penelitian akan banyak ditentukan oleh formulasi dari rumusan masalahnya dan jenis data yang akan diperoleh. Data yang biasanya berupa data primer, dapat beralih ke data sekunder, terlebih lagi di era pandemi Covid-19 saat ini. Teknik pengumpulan data yang relevan untuk metode deskriptif ini adalah dokumentasi, dengan tetap memungkinkan untuk menggunakan teknik yang lain, namun diposisikan sebagai teknik pengumpulan data pendukung. Sedangkan untuk analisis datanya, maka alternatif yang tersedia adalah dengan menggunakan statistik deskriptif untuk data kuantitatif dan analisis logis untuk data kualitatif. Dari ketiga jenis penelitian deksriptif ini, jenis yang paling komprehensif adalah jenis campuran, karena peneliti akan dapat memberikan narasi mengenai suatu kebijakan sekaligus memberi tahu pembaca mengenai implementasi dari kebijakan tersebut.
\end{abstract}

\section{Kata kunci: Penelitian Kebijakan, Deskriptif Kuantitatif, Deskriptif Kualitatif, Deskriptif Campuran}

\section{PENDAHULUAN}

Perkuliahan adalah suatu proses belajar panjang yang dijalani oleh mahasiswa untuk menjadi individu yang lebih baik. Panjang dalam pengertian bahwa belajar tersebut tidak dapat diselesaikan dalam waktu hari atau bulan. Panjang dalam makna bahwa tidak sedikit mahasiswa yang kemudian terhenti, karena berbagai alasan, di tengah jalan. Menjadi individu yang lebih baik adalah dalam pengertian bahwa perkuliahan itu adalah sebuah proses belajar, dan belajar memiliki tujuan akhir untuk berubah, apapun bentuk perubahan tersebut, dan akumulasi beragam perubahan itu membentuk karakter individu yang khas.

Perkuliahan adalah tahapan pendidikan setelah pendidikan menengah, dan tempat perkuliahan itu dilakukan adalah di perguruan tinggi. Undang-undang yang mengatur mengenai perguruan tinggi ini adalah UU Nomor 12 Tahun 2012 mengenai Pendidikan Tinggi. Dalam UU ini, pendidikan tinggi didefinisikan sebagai jenjang pendidikan setelah pendidikan menengah yang mencakup program diploma, sarjana, magister, doktor, profesi, serta program spesialis yang diselenggarakan oleh perguruan tinggi. Pasal 59 UU ini menyebutkan terdapat 5 bentuk perguruan tinggi, yaitu universitas, institut, sekolah tinggi, politeknik, akademi, dan akademi komunitas. Tidak banyak perbedaan mendasar antara kelima bentuk pendidikan tinggi tersebut, namun satu hal yang harus dilakukan dalam setiap bentuk pendidikan adalah melaksanakan fungsi dan peran perguruan tinggi melalui kegiatan Tridharma, yaitu pendidikan dan pengajaran, penelitian, dan pengabdian pada masyarakat.

Mahasiswa sebagai salah bagian dari civitas akademika, tidak terlepas dari keharusan melaksanakan Tridharma tersebut. Pendidikan dan pengajaran pada mahasiswa lebih ditekankan pada aspek pendidikan, dimana mahasiswa menerima pembelajaran 
dari dosen. Pengabdian masyarakat dilakukan oleh mahasiswa antara lain dalam bentuk kuliah kerja nyata (KKN). Dan fungsi Tridharma terakhir adalah penelitian, dimana mahasiswa juga harus melakukan penelitian sebagai salah satu syarat untuk dapat menyelesaikan pendidikan tingginya. Penelitian yang dilakukan mahasiswa kemudian disebut dengan skripsi.

Kewajiban untuk menyusun skripsi bagi mahasiwa berlaku di semua perguruan tinggi, termasuk di Universitas Pendidikan Mandalika Mataram, sebuah nama baru di dunia pendidikan tinggi di Indonesia, yang merupakan gabungan antara IKIP Mataram dan Universitas Nusa Tenggara Barat (UNTB). Dalam proses penyusunan skripsi, khususnya di UNDIKMA, mahasiswa hampir selalu terkondisikan untuk melakukan penelitian dengan pendekatan kuantitatif, yang merupakan penelitian yang menganalisis data sampel menggunakan metode statistik tertentu, untuk kemudian hasilnya digeneralisasikan ke populasi asal sampel. Dapat dikatakan bahwa hampir tidak dapat ditemukan skripsi mahasiswa UNDIKMA yang menggunakan paradigma berbeda selain dari pendekatan kuantitatif, meskiput terdapat pendekatan lain yang sebenarnya dapat digunakan oleh mahasiswa dalam penyusunan skripsi, yaitu pendekatan kualitatif atau mixed-method. Tapi nampaknya mahasiswa dan atau peraturan lembaga belum mengatur dengan baik alternatif metodologi selain dari pada pendekatan atau penelitian kuantitatif.

Diskusi mengenai pendekatan atau metodologi penelitian bukan lah pembicaraan mengenai baik atau tidaknya metode tersebut. Masing-masing pendekatan atau metodologi memiliki keunggulan dan kelemahannya tersendiri. Namun jika hampir semua skripsi mahasiswa menggunakan metode yang sama, misalkan pendekatan kuantitatif, maka saat ini, perpustakaan kampus akan penuh dengan hasil-hasil penelitian yang mungkin lemah dalam basis teoritis konseptualnya. Dan mungkin keadaan dapat menjadi lebih buruk, yaitu potensi plagiarisme dan duplikasi atau replikasi hasil penelitian menjadi semakin besar.

Mahasiswa dan setiap civitas akademika di UNDIKMA perlu membuka diri dengan konsep atau pendekatan lain dalam penelitian. Dari beragam jenis atau pendekatan penelitian, salah satu bentuk penelitian yang relevan untuk dikembangkan adalah penelitian atau studi mengenai kebijakan. Sebagian besar program studi yang ada di UNDIKMA adalah berkaitan dengan kependidikan, maka studi kebijakan yang dapat dilakukan tentunya yang berkaitan dengan dunia pendidikan.

Penelitian kebijakan pendidikan ini akan menjadi lebih menarik dengan konsiderasi bahwa pendidikan merupakan kebutuhan dasar dan hak asasi setiap manusia. Pendidikan yang baik antara lain ditentukan oleh bagaimana programprogramnya dirumuskan sedemikian dalam sebuah kebijakan, kemudian kebijakan tersebut diimplementasikan, dan di bagian akhir adalah mengevaluasi tingkat ketercapaian dari kebijakan itu. Ketika prosedur penelitian kebijakan dilakukan dengan baik, maka mahasiswa tidak hanya belajar tentang sesuatu yang baru (kebijakan itu sendiri), tapi sekaligus melatih mereka untuk berpikir kritis, merangkai satu cerita utuh dari beberapa potongan cerita, dan menarik kesimpulan akhir mengenai akhir dari cerita tersebut. Melakukan penelitian kebijakan berarti tidak sekedar menceritakan mengenai bagaimana bentuk atau gambaran sebuah kebijakan, tapi lebih pada melakukan analisis yang bersifat komprehensif terhadap suatu kebijakan. Komprehensif, dalam beberapa pengertian analisis kebijakan yang disebutkan oleh Fattah (2012), berarti bahwa kebijakan yang diteliti atau dianalisis menggunakan argumentasi rasional, dengan menggunakan fakta empirik, dan melibatkan beberapa disiplin keilmuan. Dengan melakukan penelitian kebijakan, seorang mahasiswa akan belajar memotret sesuatu dengan komprehensif dan secara langsung 
akan membuatnya memiliki pemahaman yang lebih luas dan lebih baik, khususnya dalam bidang pendidikan.

Berdasarkan pertimbangan di atas, maka tulisan ini disusun untuk memberikan alternatif baru bagi mahasiswa dan civitas akademika UNDIKMA dalam melakukan salah satu dari Tridharma perguruan tinggi yang terkait dengan penelitian. Secara khusus, tulisan ini bertujuan untuk memberikan gambaran awal mengenai apa itu kebijakan dan studi kebijakan, contohcontoh kebijakan yang mungkin untuk diteliti, dan metodologi yang dapat digunakan dalam melakukan suatu penelitian kebijakan. Jika dapat diterapkan, penelitian kebijakan dapat menjadi warna baru dan $a$ fresh scientific oasis yang dapat mengurangi kejenuhan terhadap konteks penelitian yang selama ini seolah menjadi satu-satunya pilihan.

\section{PEMBAHASAN}

\section{Kebijakan Pendidikan}

Kata "kebijakan" adalah sinonimdari kata Bahasa Inggris policy. Dalam Kamus Besar Bahasa Indonesia, kata kebijakan berasal dari kata "bijak" yang berarti selalu menggunakan akal budinya; pandai; mahir.

Sedangkan kebijakan memiliki beberapa arti sebagai berikut:

- kepandaian, kemahiran, kebijaksanaan;

- rangkaian konsep dan asas yang menjadi garis besar dan dasar rencana dalam pelaksanaan suatu pekerjaan, kepemimpinan, dan cara bertindak (tentang pemerintahan, organisasi, dan sebagainya);

- pernyataan cita-cita, tujuan, prinsip, atau maksud sebagai garis pedoman untuk manajemen dalam usaha untuk mencari sasaran; garis; haluan.

Kata policy dalam beberapa Kamus Bahasa Inggris (online) didefinisikan sebagai berikut:

- A set of ideas or a plan of what to do in particular situations that has been agreed to officially by a group of people, a business organization, a government, or a political party.

- A definite course or method of action selected from among alternatives and in light of given conditions to guide and determine present and future decisions; $A$ high-level overall plan embracing the general goals and acceptable procedures especially of a governmental body.

- A deliberate system of principles to guide decisions and achieve rational outcomes. A policy is a statement of intent, and is implemented as a procedure or protocol (Wikipedia).

Beberapa referensi ber-Bahasa Inggris, seperti dikutip oleh Sugiyono, memaknai kata policy sebagai berikut:

- Panduan yang berisi parameter-parameter untuk menetapkan atau membuat keputusan

- Panduan yang bersifat umum yang menuntun pada pencapaian sasaran/tujuan. Karena bersifat umum, suatu kebijakan tidak menyebutkan secara detail suatu tindakan, namun lebih pada penentuan batasan-batasan dalam bertindak.

- Bukan merupakan sebuah keputusan, tapi lebih sebagai suatu ruang lingkup dari keputusan tersebut, yang dapat berupa ucapan lisan, tulisan, baik yang disampaikan secara tersurat atau tersirat.

- Segala sesuatu yang dikatakan dan dilakukan, atau tidak dilakukan oleh pemerintah, dan menjadi tujuan dari program pemerintah.

Berdasarkan definisi-definisi di atas, satu hal yang dapat dikonfirmasi adalah bahwa tidak terdapat satu formulasi definisi yang sama. Dari definisi-definisi di atas, kebijakan dapat dibatasi berdasarkan beberapa indikator sebagai berikut:

- Kebijakan dibuat untuk mencapai suatu tujuan atau sasaran yang bersifat rasional dan didasarkan pada kebutuhan. 
- Kebijakan bersifat umum dalam pengertian bahwa ia harus dapat mengakomodasi kelompok-kelompok yang berkepentingan.

- Kebijakan bersifat umum karena ia berupa panduan umum non teknis. Bahkan tidak jarang, sebuah kebijakan hanya berupa satu kalimat saja.

- Kebijakan juga dapat bersifat spesifik atau khusus, ketika ia berisikan panduan atau metode yang menuntun apa yang harus dilakukan dan apa yang tidak.

- Kebijakan adalah dasar dalam membuat keputusan (decisions)

- Kebijakan dapat dinyatakan dalam bentuk tulisan atau lisan, baik secara tersurat maupun tersirat.

Meskipun kebijakan memiliki beberapa indakator seperti di atas, dalam penggunaannya, sering kali kata ini dimaknai sama dengan keputusan dan peraturan. Ketika seseorang menyebut keputusan atau peraturan, maka secara implisit merujuk pada konteks kebijakan. Sumantri (2002) menyebutkan bahwa kebijakan atau kebijaksanaan berarti ketentuan-ketentuan yang harus dijadikan pedoman, pegangan, atau petunjuk bagi setiap usaha dari aparatur pemerintah sehingga tercapai kelancaran dan keterpaduan dalam mencapai tujuan tertentu. Kebijakan tersebut kemudian dinyatakan dalam bentuk tertulis, guna memudahkan pelaksana dalam memahami dan mengimplementasikannya. Beberapa contoh kebijakan menurut Sumantri adalah seperti peraturan perundang-undangan, peraturan pemerintah, keputusan presiden, instruksi presiden, peraturan menteri, keputusan menteri, begitu seterusnya hingga sampai level terendah dalam sebuah sistem pemerintahan.

Kebijakan sendiri bukan merupakan sebuah produk final yang dibentuk dalam satu kali proses pembentukan. Kebijakan bersifat siklikal, yang akan terus dinamis sesuai dengan dinamika kelompok dan kebutuhan yang menyertai kelompok- kelompok tersebut. Dalam format yang paling sederhana, kebijakan sebagai sebuah siklus berawal dari perumusan yang merupakan rangkaian proses panjang. Setelah diperoleh rumusan kebijakan yang definitif, kebijakan tersebut kemudian diimplementasi, dan dilakukan monitoring dalam pengimplementasiannya. Dalam proses implementasi atau setelah pengimplementasiannya, kebijakan dievaluasi untuk memperoleh data empirik mengenai efektivitas kebijakan dalam mencapai tujuannya. Data dan rekomendasi hasil evaluasi kemudian dijadikan sebagai konsideran atau pertimbangan dalam

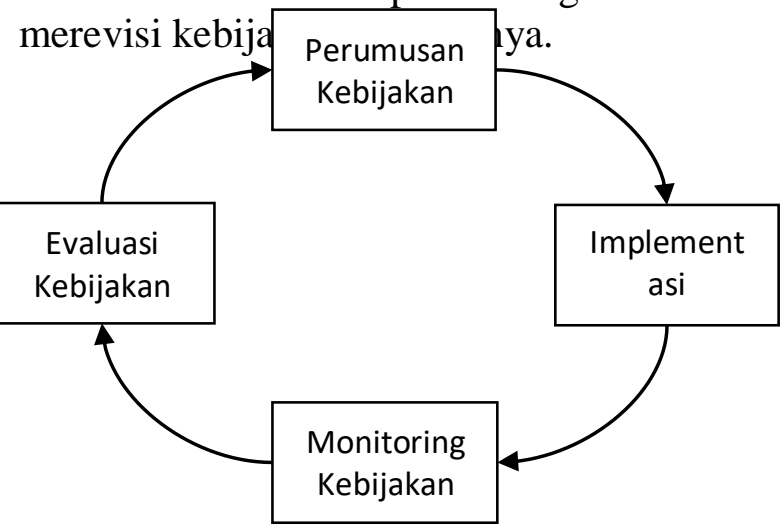

Gambar 1. Siklus Kebijakan

Berdasarkan pengertian kebijakan di atas, maka yang dimaksud dengan kebijakan pendidikan tentu adalah kebijakan pemerintah yang berhubungan dengan sektor pendidikan. Cukup contoh kebijakan yang dapat ditemukan dalam sektor ini, seperti mengenai perubahan kurikulum, BOS, BOP, pendidikan budaya dan karakter, internalisasi muatan lokal dalam kurikulum, komite sekolah, kebijakan yang terkait PPDB untuk setiap jenjang pendidikan formal, pembelajaran di masa pandemi seperti saat ini (Covid-19), dan lain sebagainya. Meskipun kebijakan dapat berupa lisan, namun tentu akan jauh lebih mudah dalam banyak konteks, jika kebijakan tersebut disajikan dalam bentuk tertulis dan eksplisit, 
sehingga dapat lebih mudah dipahami, diimpelentasikan, hinga dievaluasi.

Jika konteks kebijakan secara umum memiliki cakupan dalam skala nasional hingga daerah, luas dan spesifik, maka kebijakan pendidikan juga seperti itu. Kebijakan di bidang pendidikan dapat dikeluarkan oleh presiden di level tertinggi hingga kepala desa sebagai bentuk pemerintahan formal terkecil, atau oleh pimpinan perguruan tinggi hingga pimpinan lembaga pendidikan pra sekolah. Dengan cakupan yang sangat luas ini, tentu dapat dibayangkan bagaimana melimpahnya isu atau tema yang dapat diangkat dalam sebuah penelitian kebijakan.

\section{Penelitian Kebijakan Menggunakan Metode Deskriptif}

Metode paling sederhana yang dapat digunakan dalam penelitian kebijakan adalah metode deskriptif. Hal ini didasarkan pada pertimbangan bahwa salah satu tujuan dari penelitian adalah untuk menggambarkan suatu fenomena atau area of interest.Meskipun bertujuan untuk mendeskripsikan, bukan berarti peneliti tidak melakukan analisis yang layak terhadap data penelitian. Skripsi sebagai sebuah karya ilmiah mahasiswa S1 tidak hanya berisikan deskripsi data dan menyerahkan interpretasi data kepada pembacanya. Mahasiswa yang menyusun skripsi dituntut untuk dapat menganalisa atau memberikan interpretasinya secara obyektif ilmiah terhadap setiap data yang diperolehnya. Karena itu, meskipun metode yang digunakan adalah deskriptif, penulis skripsi tetap harus melakukan analisis yang layak terhadap data hasil penelitian.

Untuk dapat melakukan analisis yang layak, maka harus berangkat dari bagaimana permasalahan ditentukan dan dirumuskan. Perumusan masalah perlu dinyatakan sedemikian rupa sehingga dapat mengarahkan mahasiswa untuk berpikir pada level higher order thinking skills. Rumusan masalah yang menggunakan kata tanya seperti apakah, siapakah, atau dimanakah, adalah bentuk pertanyaan yang tidak relevan dengan tuntutan penyusunan skripsi. Dalam penelitian kebijakan dengan metode deskriptif, peneliti perlu mengajukan pertanyaan dengan kata tanya "bagaimana" atau "kenapa", karena dengan kata tanya ini, penelitian tidak hanya memberikan deskripsi data, namun sekaligus juga menyajikan analisis kritis yang dilakukan oleh peneliti berdasarkan deskripsi data yang diperoleh.

Metode deskriptif

dapat dikelompokkan menjadi 3 berdasarkan jenis data yang akan akan diperoleh dalam suatu penelitian, yaitu deskriptif kuantitatif, deskriptif kualitatif, dan deskriptif campuran. Metode deskriptif kuantitatif dipilih jika permasalahan dirumuskan sedemikian rupa dan data hasil penelitian seluruhnya berupa data numerik atau kuantitatif. Contoh kasus untuk metode ini seperti penelitian mengenai pemerataan peserta didik baru atau distribusi guru dan sumber daya pendidikan lainnya sebagai dampak dari implementasi kebijakan sistem zonasi. Atau misalkan penelitian mengenai dampak penerapan Kurikulum 2013 terhadap kemampuan siswa dalam menyelesaikan soal-soal HOTS. Atau contoh lainnya adalah implementasi kebijakan pengalokasian dana desa di sektor pendidikan. Beberapa contoh penelitian ini merupakan penelitian dengan metode deskriptif kuantitatif karena data hasil penelitian berupa data angka.

Alasan lain metode ini disebut dengan deskriptif kuantitatif adalah karena fokus penelitian, atau sering disebut dengan variabel, hanya terdiri dari 1 variabel. Meskipun tetap terbuka peluang bagi peneliti mengangkat lebih dari 1 variabel, namun ia tidak sampai pada proses analisis keterkaitan antar variabel. Jika lebih dari 1 variabel, maka analisis hanya akan dibatasi pada deskripsi dari tiap-tiap variabel. Teknik analisis data yang relevan untuk metode ini adalah menggunakan statistik deskriptif, meskipun peneliti masih memiliki peluang untuk menggunakan statistik inferensial jika 
data diperoleh dari sampel. Teknik statistik deskriptif merupakan teknik analisis yang sederhana dan mudah untuk dilakukan, namun memiliki nilai informasi yang sangat berharga, jika peneliti dapat membaca dan menceritakan pola, trend, atau bahkan mungkin juga untuk memberikan prediksi terhadap kejadian di masa yang akan datang. Jadi teknik analisis statistik deskriptif tidak selesai pada penyebutan rata-rata, simpangan baku, penyajian dalam bentuk diagram atau penyusunan distribusi frekuensi.

Metode penelitian kebijakan yang kedua adalah deskriptif kualitatif. Sesuai namanya, maka dalam metode ini, data yang dikumpulkan adalah data kualitatif atau data non numerik. Metode ini dapat menjadi pilihan jika fokus penelitian adalah pada aspek rumusan kebijakannya. Misalkan penelitian mengenai kebijakan sistem zonasi. Dengan menggunakan metode deskriptif kualitatif, seorang peneliti hanya bertugas untuk mendeskripsikan atau menarasikan beberapa hal seperti berikut: bagaimana proses kebijakan tersebut dibuat, dari awal hingga saat ini; perubahan apa saja yang terjadi dalam kebijakan tersebut apa yang menjadi landasan filosofisnya, bagaimana bentuk rumusan kebijakannya dari level tertinggi (presiden atau menteri) hingga level terendah (di level sekolah); dan bagaimana kesesuaian antara satu formulasi kebijakan dengan formulasi kebijakan yang lain. Seluruh data yang diperoleh dalam metode penelitian deskriptif kualitatif ini adalah berbentuk teks dan seluruhnya dinarasikan oleh peneliti.

Misalkan penelitian mengenai dana desa, dengan fokus pada bidang pendidikan. Seorang peneliti tertarik untuk mengetahui lebih jauh mengenai bagaimana pemerintah desa mendukung program pemerintah dalam bidang pendidikan. Dengan kewenangan dalam mengelola dana desa, bagaimana pemerintah desa mengeluarkan kebijakan untuk membangun pendidikan di desanya. Peneliti akan bercerita, berdasarkan fakta empirik, mengenai bagaimana proses sebuah kebijakan di tingkat desa dibuat. Pada tahap berikutnya, peneliti perlu melihat kesesuaian antara kebijakan yang dibuat oleh pemerintah desa dengan yang dibuat oleh institusi pemerintah yang ada di atasnya, misalkan di tingkat kecamatan, kabupaten, provinsi, bahkan hingga tingkat nasional. Narasi mengenai kebijakan pada berbagai level pemerintahan tersebut diperlukan untuk memperoleh gambaran mengenai kesesuaian antara satu kebijakan dengan yang lainnya. Pemeriksaan kesesuaian ini menjadi penting dalam sebuah kegiatan penelitian (baca: analisis) kebijakan, karena setiap kebijakan diterapkan untuk mencapai tujuan-tujuan yang bersifat pragmatis.

Teknik analisis data yang digunakan dalam metode deskriptif kualitatif adalah analisis logis. Sama seperti di metode deskriptif kuantitatif, dalam analisis logis, seorang peneliti mencoba mencari dan menjelaskan pola dan kecenderungan dari seluruh data kualitatif yang diperoleh. Data awal yang diperoleh dalam metode deskriptif kualitatif akan sangat banyak, dan proses analisis data seperti pengumpulan data, reduksi data, display data, pembahasan dan penarikan kesimpulan adalah tahapan yang harus dilakukan dalam analisis logis. Tujuan akhirnya tentu adalah untuk menarik kesimpulan; dan kesimpulan ini harus didasarkan pada data empirik spesifik.

Alternatif metode terakhir dalam metode deskriptif adalah metode campuran, yang menggabungkan antara data kuantitatif dan kualitatif. Misalkan dalam contoh penelitian mengenai kebijakan sistem zonasi dan tujuannya untuk pemerataan peserta didik baru. Dalam metode campuran, peneliti akan mengawalinya dengan narasi mengenai kebijakan sistem zonasi dan kemudian memotret bagaimana pemerataan peserta didik baru terjadi sebagai imbas dari penerapan kebijakan ini. Atau seperti contoh sebelumnya, mengenai penggunaan dana desa di sektor pendidikan. Metode campuran dapat digunakan untuk memberikan gambaran mengenai bagaimana bentuk atau 
formulasi kebijakan yang dibuat untuk membangun sektor pendididikan dan sekaligus menyajikan data angka mengenai implementasi dari kebijakan tersebut.

Hal penting lain yang juga perlu dipertimbangkan oleh peneliti adalah mengenai sumber data. Berdasarkan sumbernya, maka data dibagi menjadi 2, yaitu data primer dan data sekunder. Data primer adalah data yang diperoleh dari first hand atau sumber pertama atau subyek yang menghasilkan data. Misalkan data mengenai jumlah siswa baru di SMP. Data primer berarti data yang diperoleh langsung dari pihak sekolah. Atau data mengenai kebijakan kepala desa dalam pengelolaan dana desa, maka data primer yang dimaksud adalah data yang diperoleh langsung dari kantor kepala desa atau individu yang bekerja di sana. Teknik pengumpulan data yang dapat digunakan untuk metode deskriptif ini adalah dokumentasi, dimana peneliti akan mengumpulkan dokumen-dokumen yang berisi data yang relevan dengan konteks penelitian. Teknik yang lain seperti tes, kuisioner, wawancara, dan observasi dapat dilakukan dan ditempatkan sebagai data pendukung.

Idealnya, data memang seyogyanya diperoleh langsung dari sumber pertama. Namun ini bukanlah sebuah keharusan yang bersifat mutlak. Dengan berbagai pertimbangan, peneliti dapat menggunakan data sekunder, atau data yang diperoleh bukan dari sumber pertama. Contoh data sekunder ini misalkan adalah data digital yang diperoleh dari pusat-pusat data online. Misalkan di bidang pendidikan, data mengenai banyak aspek pendidikan dapat diperoleh di DAPODIK. Penggunaan data sekunder menjadi lebih relevan jika jenis penelitian deskriptif yang dipilih adalah deskriptif kualitatif. Dalam metode ini, peneliti akan lebih banyak berkunjung ke perpustakaan-perpustakaan baik yang konvensional maupun digital. Di era digitalisasi dan otomatisasi saat ini, begitu banyak hal dapat dijumpai di internet.
Konsep big data adalah sebuah keniscayaan dan setiap orang, khususnya mahasiswa semakin dituntut untuk memiliki literasi digital yang memadai.

Penentuan metode deskriptif mana yang akan digunakan akan banyak ditentukan oleh formulasi rumusan masalah. Jika rumusan masalah secara tersirat atau tersurat menghendaki data berbentuk angka, maka jenis penelitian yang digunakan adalah deskriptif kuantitatif. Jika jawaban terhadap rumusan masalahnya akan berupa narasi kualitatif, tentu jenisnya adalah deskriptif kualitatif. Namun, jika seorang peneliti memiliki keleluasaan dalam hal waktu, tenaga, dan biaya, maka tentu akan lebih optimal jika ia menggabungkan kedua jenis penelitian deskriptif ini. Dengan metode campuran, pembaca akan memperoleh gambaran yang lebih lengkap pada satu hasil penelitian, dimana pembaca akan memperoleh gambaran mengenai bentuk kebijakan yang dibuat sekaligus mengetahui bagaimana implementasinya di lapangan.

\section{PENUTUP}

Skripsi mahasiswa kependidikan

perlu lebih diperkaya dengan tema-tema baru. Pendidikan sendiri merupakan suatu bidang yang sangat kompleks dan begitu luas. Selama ini, penelitian yang dilakukan oleh mahasiswa untuk keperluan skripsi masih sangat terbatas pada konteks pembelajaran atau manajemen pendidikan. Tema penelitian skripsi mahasiswa perlu untuk menyentuh sisi lain dari dunia pendidikan, yaitu yang terkait kebijakan pendidikan.

Pada dasarnya, metode penelitian kebijakan adalah sama dengan metode penelitian pada umumnya. Yang membedakan adalah dalam hal isu utamanya, yaitu mengenai kebijakan yang berhubungan dengan sektor pendidikan. Alternatif metode pertama yang dapat digunakan oleh mahasiswa adalah metode deskriptif, yang 
terdiri dari 3 jenis, yaitu deskriptif kuantitatif, deskriptif kualitatif, dan deskriptif campuran. Pemilihan jenis penelitian akan banyak ditentukan oleh formulasi dari rumusan masalahnya dan jenis data yang akan diperoleh. Data yang biasanya berupa data primer, dapat beralih ke data sekunder, terlebih lagi di era pandemi Covid-19 saat ini. Teknik pengumpulan data yang relevan untuk metode deskriptif ini adalah dokumentasi, dengan tetap memungkinkan untuk menggunakan teknik yang lain, namun diposisikan sebagai teknik pengumpulan data pendukung. Sedangkan untuk analisis datanya, maka alternatif yang tersedia adalah dengan menggunakan statistik deskriptif untuk data kuantitatif dan analisis logis untuk data kualitatif. Dari ketiga jenis penelitian deksriptif ini, jenis yang paling komprehensif adalah jenis campuran, karena peneliti akan dapat memberikan narasi mengenai suatu kebijakan sekaligus memberi tahu pembaca mengenai implementasi dari kebijakan tersebut.

\section{DAFTAR PUSTAKA}

Fattah, Nanang (2012). Analisis Kebijakan Publik. Bandung: PT Remaja Rosdakarya, hh. $3-5$.

https://kbbi.web.id/bijak

https://dictionary.cambridge.org/dictionary/e nglish/policy

https://www.merriamwebster.com/dictionary/policy

https://en.wikipedia.org/wiki/Policy\#

Sugiyono (2017). Metode Penelitian Kebijakan: Pendekatan Kuantitatif, Kualitatif, Kombinasi, $R \& D$, dan Penelitian Evaluasi. Bandung: Alfabeta, hh. $1-2$.

Sumantri, D. A (2002). Tentang Kebijaksanaan Pemerintah. Fakultas Hukum UI, Jurnal Hukum dan Pembangunan Nomor 1 Tahun XXXII, Volume 32 No 1 Tahun 2002, hh 39 50 . 